\title{
Definice terorismu
}

\author{
Huy Ho Ba \\ Západočeská univerzita, Fakulta právnická
}

Anotace: Tento príspěvek má za cil nastínit problematiku definice terorismu, který má přesah do více oborů. Dodnes se $v$ mezinárodních organizacích, například Organizaci spojených národů nebo Evropské unii, neshodli na definici. $\checkmark$ přispěvku jsou rozebrány těžkosti a překážky při této činnosti. Zabývá se vývojem terorismu, určitými způsoby provedení, pokusy o definici a naznačuje připadné problémy, které mohou vyvstat kvůli chybějící pevné definici. $V$ neposlední řadě rozebirá úpravu v tuzemském trestním řádu.

Kličová slova: terorismus, definice terorismu, vývoj terorismu

Abstract: This article focuses on the definition of terorism, which cross multiple disciplines. Till today, international organizations, such as the United Nations or the European Union have not agreed on its definition. The article discusses difficulties in this activity, evolution of terrorism itself, methods of commiting it, multiple attemps of definition and suggests possible problems that may arise due to the lack of definition. It also examins on the regulation in the Criminal Code of Czech Republic.

Keywords: terrorism, definition of terrorism, evolution of terrorism 


\section{Úvod}

V tomto príspěvku se budu snažit najít definici terorismu. Zaměřím se například na to, které nosné prvky obsahuje definice a zda je vůbec terorismus definován v právních předpisech. Pokud ne, chci najít, zda dochází k pokusům o harmonizaci definice, např́klad v Organizaci spojených národů či Evropské unii.

Tato definice je podle mého názoru vytvořeného $z$ rešerší jedna z důležitých definic, které by bylo dobré zařadit do každého právního řádu.

V tuzemském trestním zákoníku máme definovaný například teroristický útok, teror, nikoliv však terorismus jako takový. Harmonizace, tedy všeobecná mezinárodní shoda na této definici, která by byla celosvětově uznávaná, by mohla pomoci ve větší vymahatelnosti práva, zejména $v$ tom směru, aby pachatelé nemohli najít případné mezery $v$ právních předpisech a nevyvázli z určitých trestných činů bez trestu, i když je velmi dobře podchycená legislativa $v$ tomto směru. Jeden z mnoha příkladů, které je možno uvést, je třeba směrnice AML (Anti Money Laundering) na území Evropské unie, která se promítá následně v právních řádech členských zemí a jež se kromě výnosů z trestné činnosti zabývá financováním terorismu. Kde nejsou finance, tam také nic není.

V příspěvku se budu zabývat původem slova terorismus, jeho historickým vývojem a v neposlední řadě právní úpravou. 


\section{Původ slova a jeho význam}

Slovo terorismus, podle etymologického slovníku, pochází z francouzského slova terreur, což ve francouzštině znamená něco zastrašovat nebo předmět strachu'. Další prameny uvádí, že slovo terorismus pochází z latinského slova terrorem ${ }^{2}$, což znamená velký strach či panika.

Obecně jde o psychologický nátlak, vydírání, strach a nejistotu celé společnosti či určité skupiny obyvatel dané země. Cílem je zmocnění se myšlenek obyvatelstva, nejde tu o územní zisky jako ve válce, ale pouze o znejistění a vyvolání pocitu strachu.

Podle studie Schmida a Jongmana z roku 1983 se už v této době vyskytovalo až $109^{3}$ odlišných definic terorismu, které kolovaly $v$ akademické a expertní obci.

Knihy, které sloužily jako podklady $k$ tomuto přispěvku a k porozumění definice, už na samotném začátku tvrdí, že samotná definice je velmi těžko uchopitelná, a zdůrazňují, že nelze určit jednotnou definici pro všechny obory.

Musíme si uvědomit, že problematika terorismu je velmi rozsáhlá a nezasahuje pouze do práva, ale má přesah i do oborů, jako je psychologie, sociologie a další, které sleduji stejný fenomén, pouze jinou optikou.

${ }^{1}$ Terror (n.). Online Etymology Dictionary [online]. [cit. 2019-07-28]. Dostupné z: https://www.etymonline.com/word/terror

${ }^{2}$ Terreo. Glosbe [online]. [cit. 2019-07-31]. Dostupné z: https://cs.glosbe.com/la/cs/terreo ${ }^{3}$ SCHMID, A. - JONGMAN, A. Political Terrorism: A new Guide to Actors, Authors, Concepts, Data bases, Theories \& Literature. 1983, s. 8. 
Je nutné dodat, že každá organizace či instituce, které se snaži definovat tento pojem, maji tendenci jej pojmout pouze ze svého pohledu a neohliži se po ostatních nebo se nedostatečně na ně soustředí. Navíc se význam definice terorismu mění $s$ časem a hlavně $s$ událostmi, které nás postihovaly $\checkmark$ minulosti a postihuji dnes. Podrobněji se budu vývojem terorismu zabývat $\mathrm{v}$ další kapitole.

Jedním z mnoha problémů je, že každý stát vnímá rozdílně terorismus, má jiný pohled na něj a dává mu jiný význam. Nepanuje tu stále všeobecná shoda a nevypadá to, že by se to mělo $v$ nejbližši době změnit. Další z problémů může být v rozlišení terorismu a guerillové války, zejména $v$ oblasti Blízkého východu. Jako názorný př́iklad nám může posloužit Palestina, která nebude Hamás řadit mezi teroristické organizace.

Pokus o harmonizaci definice terorismu v mezinárodním právu už tu byl. A nebyl to pouze jeden! Návrhy padaly zejména $v$ dobách, kdy docházelo $\mathrm{k}$ větším teroristickým útokům, které otřásly světem. Poslední návrh je od Indie z roku $1986^{4}$ na půdě Organizace spojených národů.

Jeden z obecných pojmů, které můžeme najit, je třeba z oxfordského slovníku, a to "the unlawful use of violence and intimidation, especially against civilians, in the pursuit of political aims“, 5 v doslovném překladu tedy „protiprávní použití

\footnotetext{
${ }^{4}$ India gives clarion call at UN to adopt CCIT after Azhar blacklisting. The Economics Times India [online]. [cit. 2019-08-10]. Dostupné z: https://economictimes.indiatimes. $\mathrm{com} /$ news/defence/india-gives-clarion-call-at-un-to-adopt-ccit-after-azhar-blacklisting/articleshow/69173551.cms?from $=\mathrm{mdr}$

${ }^{5}$ Terrorism. Lexico [online]. [cit. 2019-07-28]. Dostupné z: https://en.oxforddictionaries.com/definition/terrorism
} 
násilí a zastrašování, zejména proti civilistům, při dosahování politických cílů“.

\section{Vývoj terorismu}

Činy, které by se v dnešní době daly kvalifikovat jako terorismus, byly spáchané už v 1 . století. Na svědomí je měla židovská nábožensko-politická skupina zélotů a sikariů, kteři se snažili vyprovokovat židovské povstání proti římskému útlaku. Způsob spáchání, specifický pro tuto skupinu, byl takový, že se vždy vynořili z davu a podřezali hrdla římských legionářů.

Slovo terorismus se začalo použivat až v době Francouzské revoluce $^{6}$, v období tzv. jakobínského teroru. $V$ této době jakobíni jako politická frakce pronásledovali a odstraňovali fyzicky své politické odpůrce.

Za zmínku stojí skupina asasínů z 11. století, kteří byli tajným islamistickým hnutím ${ }^{7}$, jež sledovalo své politické cíle. Jejich cílem se stali politici a klerici, kteři odmítali asasíny uznávanou verzi islámu. Napadali pomocí dýky veřejně své oběti o svátcích za bílého dne. Pokud byl vrah zabit, měl slíbený okamžitý vstup do ráje.

${ }^{6}$ GOLDER, Ben - WILLIAMS, George. What is „Terrorism“? Problems of Legal Definition. University of NSW Law Journal. 2004, sv. 27, č. 2, s 270-295. Dostupné z: https:// ssrn.com/abstract=1351612

${ }^{7}$ Asasini. In: Wikipedia: the free encyclopedia [online]. San Francisco (CA): Wikimedia Foundation, 2001. [cit. 2019-07-28]. Dostupné z: https://cs.wikipedia.org/wiki/Asas \%C3 \%ADni 
Nejplodnější ve vývoji terorismu bylo období ke konci 19. století a samotné 20 . století.

Na konci 19. století vyrůstaly v carském Rusku radikální anarchistické skupiny, které se snažily o politické atentáty. Jejich hlavním cílem bylo svržení cara.

Po první světové válce se dostali do popředí zejména nacionální teroristé, kteři se snažili dosáhnout vytvoření nového, nezávislého státu.

Vyskytuje se tu problém, na který se narazí vždy během definování terorismu. Dají se pojmout tyto činy jako terorismus, nebo jako čin bojovníka za svobodu? Tento problém nebyl pouze v období první světové války, ale potýkáme se s ním i v dnešní době. Nejznámější skupinou nacionálních teroristů je Irská republikánská armáda, též známá pod zkratkou IRA. IRA se snažila o nezávislost Irska na Velké Británii. Jelikož IRA prijala $v$ roce 2005 Velkopáteční mírovou dohodu, tato organizace už oficiálně nefunguje, ale část jejích členů toto rozhodnutí nepřijala a funguje nadále.

Další známou skupinou je španělská ETA, celým názvem Euskadi Ta Askatasuna, česky Baskicko a jeho svoboda. Tato organizace fungovala do roku 2018, kdy ukončila své působení. Maji na svědomí přes 800 obětí a některá čísla hovoři konkrétně o 854 obětech $^{8}$ za svého působení od roku 1959 do roku 2018.

${ }^{8}$ Přes 800 obětí a dalši stovky zraněných. To je bilance 50 let působení teroristické skupiny ETA. Lidovky.cz [online]. [cit. 2019-07-29]. Dostupné z: https://www.lidovky. cz/svet/pres-800-obeti-a-dalsi-stovky-zranenych-to-je-bilance-50-let-pusobeni -teroristicke-skupiny-eta.A180504_114147_In_zahranici_ele 
Nelze ani opomenout to, že nálepkování svých oponentů termínem terorismus se vyskytovalo i v době před 2 . světovou válkou, kdy takto nazývali nacisté v Německu a fašisté v Itálii své politické oponenty s cílem zdiskreditovat jejich postavení.

V posledních letech můžeme pozorovat rostoucí vlnu teroristických činů, které jsou ovlivněny zejména radikálními výklady různých náboženství. $V$ dnešní době už nelze ani vyloučit hrozbu užití zbraní hromadného ničení.

Jedním ze smutných př́kladů je útok sarinem v roce 1995, který se stal v tokijském metru. Tento teroristický útok měla na svědomí sekta Óm šinrikjó (v překladu Nejvyšší pravda), která věřila, že vražda pomůže jak oběti, tak vrahovi ke spáse.

Nelze nepřihlédnout k obrovskému mezníku, kterým se stalo 11. záŕi 2001, kdy došlo k sérii teroristických útoků na území Spojených států amerických, a to 3 letadly American Airlines a United Airlines. Zasaženy byly budovy Světového obchodního centra v New Yorku a budova Pentagonu. Zde zahynulo více než 2700 lidi $^{9}$. Tento útok měla na svědomí organizace al-Káida fungující od roku 1988.

$\mathrm{Na}$ útoku $v$ roce 2001 můžeme vidět tendence zvyšování ochoty atentátníků k sebeobětování za vyšší cíle, vyšší organizovanost či samotnou funkčnost organizace na nové úrovni. Útoky mají za cíl zabít co nejvíce lidí a zároveň způsobit

${ }^{9}$ Sedmnáct let od teroristických útoků z 11. záŕi: znovu otevřená stanice metra i lepší testy DNA. iRozhlas [online]. [cit. 2019-07-29]. Dostupné z: https://www.irozhlas.cz/ zpravy-svet/11-zari-2001-vyroci-17-let-new-york-teroristicky-utok-dvojcata-wtc-unos -letadel_1809110626_haf 
rozsáhlé škody a hospodářské ztráty, což jsme mohli vidět u útoku z roku 2001 ve Spojených státech amerických. Sledujeme obrovský kontrast oproti minulosti, kdy teroristé chtěli, aby lidé přihliželi jejich samotnému činu, ale nebylo mnoho civilních obětí. Tento trend můžeme sledovat napřiklad na útocích ETA či IRA, kdy počty obětí byly většinou $v$ desítkách.

\section{Nosné prvky definice terorismu}

Z předchozích kapitol je jasné, že definice terorismu a variabilita jejího vnímání jsou velmi různorodé a daji se pojmout různými pohledy. Proto je dobré si stanovit, které prvky vždy obsahuje definice terorismu.

Terorismus vždy vyžaduje použití násilí, zejména fyzického, kterým je proveden teroristický útok. Dalším prvkem je označení určitého cíle, na který má být zaměřen daný teroristický útok. Zejména jde o útok bud' na obyvatelstvo, nebo majetek, či obojí.

Subjektivní stránku zahrnuje vždy úmysl. Nelze tu mluvit o nedbalosti. Neméně důležitým je záměr, se kterým pachatel páchá teroristický útok, záměr s cílem upozornit na sebe, organizaci či jiné cíle.

Definice terorismu by mohla teoreticky zahrnovat i prvky politického násilí, kterým se teroristický čin odlišuje od ostatních útoků. Jde o komunikativní násilí, respektive o předání určitého vzkazu, a asymetrii moci, kdy se malá skupina 
mobilizuje vůči silnějšímu protivníkovi, který je u moci, a tato malá skupina chce přelít vliv na svou stranu.

Napřiklad u politického násilí už nepanuje všeobecná shoda $v$ této definici. Nabízí se tedy otázka, zda chceme vůbec definovat terorismus. Za jakým účelem? Nebude lehči nechat definici být a pojmout $v$ trestních zákonících pouze činy, které z něho vyplývají, když od 30 . let nedokážeme vyřešit tuto otázku jak na půdě Společenství národ, tak posléze ani v Organizaci spojených národů?

Jak bylo zmíněno $v$ úvodu, jsou tu argumenty jako trestni odpovědnost. Základní princip trestního zákoníku v České republice je nullum crimen sine lege, tedy musí být teroristický čin samozřejmě definován $v$ trestním zákoníku, jinak bychom se vrátili do raných let 19 . století a nejpalčivějším účinkem by byla nemožnost pachatele potrestat.

Samotný pojem terorismu v trestním zákoníku není potřeba, ale například $v$ oblasti přeshraniční mezinárodní spolupráce by se tato definice mohla stát velice prínosnou. Je přirozené si definovat něco, proti čemu se má společně bojovat. V Evropské unii s tím není problém, protože zde máme mnoho právních předpisů, které pokrývají značnou část, ale ve spolupráci s ostatními státy mimo Evropskou unii by takový problém nastat mohl. Můžeme nahlédnout na dalši problém, který se vyskytl v minulosti, a to je zdiskreditování protivníků $s$ použitím této nálepky, hlavně $v$ době, kdy jsou sociální média ideální pro šíření fake news a podobných dezinformací, které jsou už i tak velmi těžce odlišitelné od pravdivých informací, zejména v kombinaci s internetovou gramotností, 
kdy je přistup, že „co je psané, to je pravda“. Absolutní katastrofa a stálé, uznávané definice by mohly trochu pomoci při vyhledávání a zjištování, zda jsou určité články pravdivé, či mají být dezinformací.

\section{Pokusy o definici}

\section{a. Společnost národů}

Už v předchozí kapitole jsem nastínil, že pokusy o definici proběhly už ve 30 . letech. Tyto pokusy probíhaly ještě za předchůdce Organizace spojených národů, na půdě Společnosti národů. Snaha o definování přišla jako reakce na zavraždění jugoslávského krále Alexandra a francouzského ministra zahraniči Barthoua v Marseille v roce 1934. Výsledkem se stala Úmluva o předcházení a potlačování mezinárodního terorismu o tři roky později, která poprvé definovala terorismus a teroristický čin ${ }^{10}$. Tato úmluva byla podepsána pouze 24 státy.

\section{b. Organizace spojených národů}

K dalšímu pokusu o definici terorismu došlo po dalším teroristickým útoku, a to během olympijských her v roce 1972 v Mnichově, který je také nechvalně známý pod názvem mnichovský či olympijský masakr, jejž spáchala teroristická skupina Černé září.

${ }^{10}$ BÍLKOVÁ, Veronika. Mezinárodni právo a terorismus. Definovat nedefinovatelné? Trestněprávní revue. 2010, č. 1, s. 11-17. 
Jedním z úspěchů na půdě OSN se stala až úmluva International Convention for the Suppression of the Financing of Terrorism (česky Mezinárodní úmluva o potlačování financování terorismu), která vstoupila v platnost 10. dubna 2002 a v České republice 26. ledna 2006. V tomto dokumentu je definován terorismus následovně: ,... maji být použity, at už plně nebo zčásti, za účelem uskutečnění jakéhokoliv jiného činu, jehož provedením je zamýšleno způsobit smrt nebo vážné tělesné zranění civilní osobě nebo jakékoliv jiné osobě nehrajíci aktivní úlohu $v$ nepraátelských akcích za situace ozbrojeného konfliktu, je-li účelem takového činu, at už $v$ důsledku jeho povahy, nebo kontextu, zastrašit obyvatelstvo nebo přinutit vládu nebo mezinárodní organizaci, aby uskutečnila nebo se zdržela uskutečnění jakéhokoliv činu. “"11

Na půdě Organizace spojených národů je stále snaha o přijetí úmluvy Comprehensive Convention on International Terrorism (česky Všeobecná úmluva o mezinárodním terorismu), kterou navrhla Indie v roce 1986, avšak ani po 33 letech státy nemohou nalézt společnou řeč.

\section{c. Evropská unie}

Evropská unie se věnuje velmi pozorně boji proti terorismu a Ize tu proto vyjmenovat mnoho nařizení a směrnic, které se snaží podchytit aktivity od financování terorismu až po konkrétní činy.

${ }^{11 U ́ m l u v a ~ c ̌ . ~ 18 / 2006 ~ S b . ~ m . ~ s ., ~ s d e ̌ l e n i ́ ~ M i n i s t e r s t v a ~ z a h r a n i c ̌ n i ́ c h ~ v e ̌ c i ́ ~ o ~ M e z i n a ́ r o d n i ́ ~}$ úmluvě o potlačování financování terorismu, článek 2. 
Již v prosinci 1995 přijala Evropská rada La Gomera Declaration (česky Deklaraci o terorismu), kde definuje terorismus následovně v pěti důležitých bodech: „1. představuje hrozbu pro demokracii, svobodné uplatňování lidských práv i ekonomický a sociální rozvoj, hrozbu, před niž se nemůže cítit uchráněn žádný členský stát EU; 2. se rozšiřil především v důsledku jednání fundamentalistickou motivací; 3. získává nadnárodni charakter, a proto mu žádný stát nemůže účinně čelit izolovanými akcemi a pouze svými prostředky; 4. uskutečňuje strategie vlastní mezinárodnímu organizovanému zločinu a bere na sebe jeho podoby; 5 . mohl by ve snaze dosáhnout beztrestnosti využivat případných rozdilů mezi justičními postupy v jednotlivých státech.“12

$\mathrm{Na}$ základě této deklarace navazovaly další kroky $\mathrm{v}$ boji proti terorismu, které můžeme vidět dnes $v$ každodenním životě, jako napřiklad směrnice AMLD5, jež byla schválena $v$ roce 2018.

\section{Definice v českém právu}

V českém trestním zákonu definici terorismu nenalezneme, ale na webových stránkách Ministerstva vnitra najdeme následujicí definici: „Terorismus je propočitané použití násilí nebo hrozby násilím, obvykle zaměřené proti nezúčastněným osobám, s cílem vyvolat strach, jehož prostřednictvím jsou dosahovány politické, náboženské nebo ideologické cíle.

${ }^{12}$ MADRID EUROPEAN COUNCIL 15 and 16 DECEMBER 1995 PRESIDENCY CONCLUSIONS. European Parliament [online]. [cit. 2019-08-10]. Dostupné z: http://www. europarl.europa.eu/summits/mad2_en.htm\#annex3 
Terorismus zahrnuje i kriminální zločiny, jež jsou ve své podstatě symbolické a jsou cestou k dosažení jiných cílů, než na které je kriminální čin zaměřen." ${ }^{13}$

Prímo v trestním zákoníku je definován teroristický útok a trestný čin teroru, a to od novely z roku $2016^{14}$.

\section{Závěr}

Z většiny příspěvku vyplývá, že definice terorismu není nejlehčím úkolem, kterého by se mohl ujmout kdejaký zákonodárce. Zejména na půdě Organizace spojených národů bude potřeba politický konsenzus a podle mého názoru je reálné, aby jednou Všeobecná úmluva o mezinárodním terorismu vešla $v$ platnost a byla ratifikována $v$ České republice, byt její vývoj od roku 1986 je poněkud bouřlivý, i s ohledem na události, které se během toho staly a bohužel se stávají každý den.

Nesmíme zapomenout, že terorismus je téma, které nás možná prímo netrápí, ale $v$ jiných částech světa právě ted' někdo bojuje o svůj život a vzdoruje psychickému nebo dokonce fyzickému nátlaku teroristů.

\footnotetext{
${ }^{13}$ Definice pojmu terorismus. Ministerstvo vnitra České republiky [online]. [cit. 201908-10]. Dostupné z: https://www.mvcr.cz/clanek/definice-pojmu-terorismus.aspx ${ }^{14}$ JELÍNEK, J. „Protiteroristická“ novela trestního zákoníku - poznámky k orientačnímu studiu. Bulletin advokacie. 2017, č. 3, str. 23-28.
} 


\section{POUŽITÉ PRAMENY}

BÍLKOVÁ, Veronika. Mezinárodní právo a terorismus. Definovat nedefinovatelné? Trestněprávní revue. 2010, č. 1, s. 11-17.

Boj EU proti terorismu. Generální sekretariát Rady [online]. [cit. 2019-08-10]. Dostupné z: https://www.consilium. europa.eu/cs/policies/fight-against-terrorism/

Definition of Terrorism - Social and Political Effects. Journal of Military and Veterans Health [online]. [cit. 2019-08-10]. Dostupné z: https://jmvh.org/article/definitionof-terrorism -social-and-political-effects/

Definice pojmu terorismus. Ministerstvo vnitra České republiky [online]. [cit. 2019-08-10]. Dostupné z: https://www. mvcr.cz/clanek/definice-pojmu-terorismus.aspx

GOLDER, Ben - WILLIAMS, George. What is ,Terrorism‘? Problems of Legal Definition (2004). University of NSW Law Journal. 2004, sv. 27, č. 2, s. 270-295. Dostupné z: https:// ssrn.com/abstract $=1351612$

JELÍNEK, Jiří. Terorismus - základní otázky trestního práva a kriminologie. Praha: Leges, 2017. Teoretik. ISBN 978-80-7502-256-1.

JELÍNEK, Jiří. „Protiteroristická“ novela trestního zákoníku - poznámky k orientačnímu studiu. Bulletin advokacie. 2017, č. 3, str. 23-28.

LUKÁŠEK, Libor. Boj s terorismem pohledem Evropské unie. Evropské právo. 2000, č. 7, s. 5-7.

MADRID EUROPEAN COUNCIL 15 and 16 DECEMBER 1995 PRESIDENCY CONCLUSIONS. European Parliament [online]. [cit. 2019-08-10]. Dostupné z: http://www.europarl. europa.eu/summits/mad2_en.htm\#annex3 
Mnichovský masakr. In: Wikipedia: the free encyclopedia [online]. San Francisco (CA): Wikimedia Foundation, 2001 [cit. 2019-08-19]. Dostupné z: https://cs.wikipedia.org/ wiki/Mnichovsk \%C3 \%BD_masakr

Směrnice Evropského parlamentu a Rady (EU) 2017/541 ze dne 15. března 2017 o boji proti terorismu, kterou se nahrazuje rámcové rozhodnutí Rady 2002/475/SVV a mění rozhodnutí Rady 2005/671/SVV.

SOULEIMANOV, Emil - BELFER, Mitchell A. Terorismus: pokus o porozumění. Praha: Sociologické nakladatelství (SLON), 2010. Sociologické aktuality. ISBN 978-80-7419-038-4.

Úmluva č. 18/2006 Sb. m. s., sdělení Ministerstva zahraničních věcí o Mezinárodní úmluvě o potlačování financování terorismu, článek 2.

Společný postoj Rady 2001/931/SZBP ze dne 27. prosince 2001 o uplatnění zvláštních opatření $\mathrm{k}$ boji proti terorismu. Terorismus $v$ dějinách a mezinárodním právu. Právní prostor [online]. [cit. 2019-08-10]. Dostupné z: https://www. pravniprostor.cz/clanky/mezinarodni-a-evropske-pravo/ terorismus-v-dejinach-a-mezinarodnim-pravu

Terorismus a měkké cíle: Trestněprávní úprava. Ministerstvo vnitra České republiky [online]. [cit. 2019-08-10]. Dostupné z: https://www.mvcr.cz/cthh/clanek/trestnepravni-uprava.aspx 